University of Nebraska - Lincoln

DigitalCommons@University of Nebraska - Lincoln

Textile Society of America Symposium

Proceedings

Textile Society of America

2020

\title{
Where Can Objects Take You? The Case of the World War II Japanese Airman's Suit
}

\author{
Madelyn Shaw \\ National Museum of American History, Smithsonian Institution \\ Trish FitzSimons \\ Griffith University, t.fitzsimons@griffith.edu.au
}

Follow this and additional works at: https://digitalcommons.unl.edu/tsaconf

Digitadrt of the Art and Materials Conservation Commons, Art Practice Commons, Fashion Design Cemmens, Fiber, Textile, and Weaving Arts Commons, Fine Arts Commons, and the Museum Studies detwerkns

Logo

Shaw, Madelyn and FitzSimons, Trish, "Where Can Objects Take You? The Case of the World War II Japanese Airman's Suit" (2020). Textile Society of America Symposium Proceedings. 1166.

https://digitalcommons.unl.edu/tsaconf/1166

This Article is brought to you for free and open access by the Textile Society of America at DigitalCommons@University of Nebraska - Lincoln. It has been accepted for inclusion in Textile Society of America Symposium Proceedings by an authorized administrator of DigitalCommons@University of Nebraska - Lincoln. 


\title{
Where Can Objects Take You? The Case of the World War II Japanese Airman's Suit
}

\author{
Madelyn Shaw and Trish FitzSimons
}

\begin{abstract}
Dad always said that "It's made out of Australian wool" and I thought that was just a joke because you couldn't see how the Japanese would get hold of Australian wool during the war ...But it is a fine material... They weren't't scrapping for something to wear.

Wally Lanagan (Dalby, Queensland, Australia, May 2019)
\end{abstract}

In December 1942, Japan's Yokosuka Military Department manufactured, surely among hundreds of others, a flying suit, which may or may not have ever been worn by a Japanese pilot. It did, however, end up on display at the volunteer-run Pioneer Park Museum in Dalby, a small town in rural Queensland, Australia.

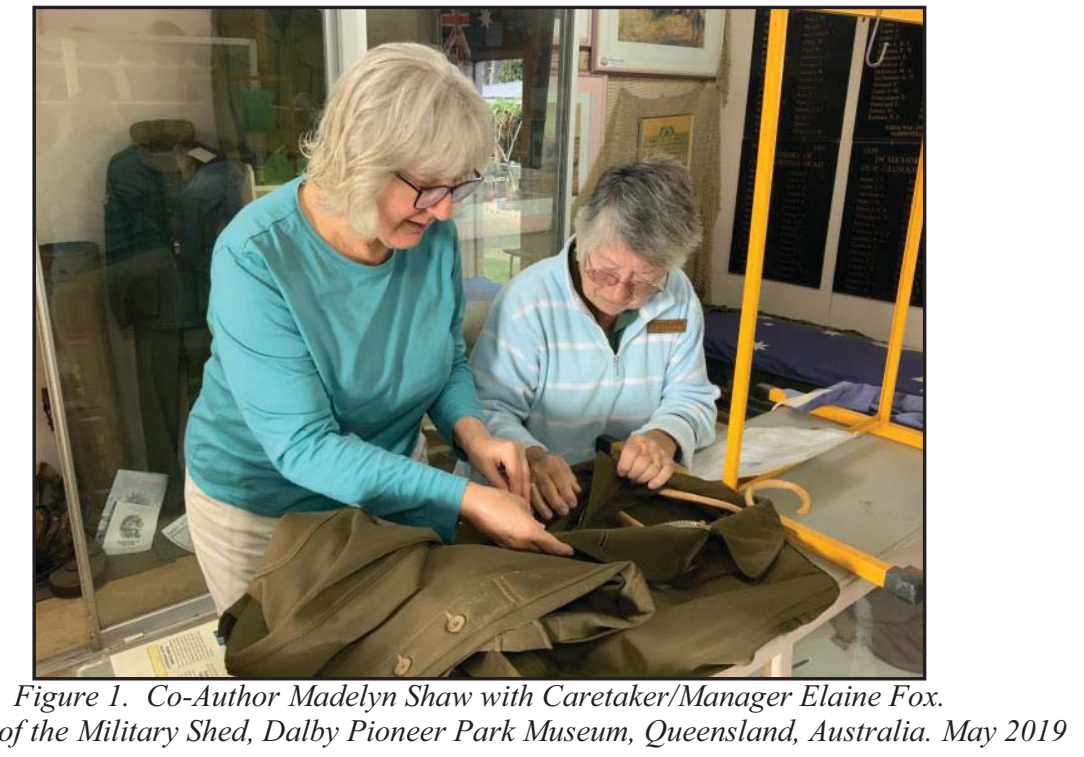

There it rested, until the authors stumbled onto it. Through the dusty glass of the display the suit had an odd sheen - was it wool? cotton? A blend? In light of the authors' focus on the role of wool in wartime, what might this textile teach us? This paper explores how far this one garment took us on our quest to understand decades of international bickering over textile resources and the role that a transitional moment in the fabrics of war - from natural to synthetic fibers - played in the political economy of war. It also discusses the process of creating a digital media interactive that will meld a 3-D scan of the suit with relevant documents, images, and text. This will allow viewers to explore the suit from a variety of perspectives, and perhaps to think 'curatorially' about how every object in a museum represents a multi-disciplinary array of stories: not just of those who used it but of those who made, sold, transported, saved, and displayed it, as well.

Our story began in May 2019, on a research trip from our base in Brisbane, Queensland, to several wool-related locations beyond the Great Dividing Range. We stopped at the Dalby Pioneer Park Museum, specifically to consult with one of the local historians about some land in 
the area with a long-ago family connection. Once there, however, we pottered about the sprawling compound, full of so much undifferentiated stuff that it would be easy to be overwhelmed. But we persevered, finally making our way into the Military Shed, so-called. And lucky that we did. One of the first object lessons in this story: do not dismiss local collections, nor assume that their contents will have purely local relevance, or that crowded displays without interpretation mean that no context exists, or can be found.

From the jumble of artifacts in the shed, most of them Australian military uniforms, provenance unknown, one piece drew us in: the Japanese airman's flying suit mentioned above. The suit was hung up in a glass-fronted wall case on a plain, uncovered rattan coat hanger. A sheet of paper with some donor information was clipped to the front. We read that it had been lent to the museum in the early 2000s by the nephew of an Australian infantry soldier in New Guinea who brought it home as a souvenir at the end of World War II.

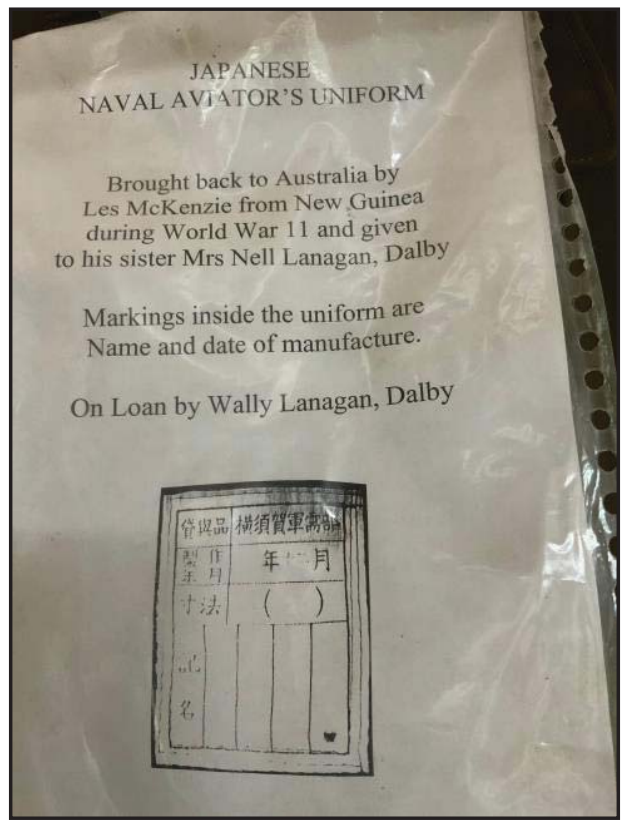

Figure 2. Typed Label of the Japanese Airman's flying suit, Dalby Pioneer Park Museum.

Trish inquired of the caretaker/manager, Elaine Fox, if we could examine the suit, and she graciously unlocked the case, and allowed us to remove it from the case and hanger. Although there was no handy "Fiber Content Label" in the suit, the textile's sheen and its smooth, almost slick surface suggested that it was a blend - almost certainly of rayon and wool - and probably a fairly fine merino wool, at that. ${ }^{1}$ As we gingerly opened the suit, checked the pockets, photographed the cloth label affixed inside the suit, and looked for wear patterns, we began to

\footnotetext{
${ }^{1}$ We were unable to arrange a chemical or burn test on the suit's yarn. Our fiber identification rests on examination with a handheld 30X magnifier, and the look and feel of the cloth in comparison with known $100 \%$ wool and wool blend fabrics of varying weights and weave structures. The blended fiber is smoother and shinier than cotton and had none of the 'scroop' of silk.
} 
think about how we might assist in making the suit available to other scholars and interested parties, as well as to how it could fit into our Fabric of War creative research project. ${ }^{2}$

After this preliminary documentation, we did a bit of conservation explanation and Elaine, somewhat skeptically, gave us an old towel to pad out the hanger with before hanger and suit were returned to the case. The preservation resources available to protect local collections are often minimal: we are hopeful that, post-pandemic, staff from the Queensland Museum will be able to help the Dalby folks out with some conservation assistance. But our own historical preservation and interpretation wheels had begun to turn as we looked more closely at the piece.

The fact that the suit was clearly partially made of wool, although wool was not among Japan's primary products, was not a surprise to us. We were already aware of Japan's importance within the 20th century's global wool trade. We have been unable to find in English any detailed monograph on the Japan-Australia wool trade, though parts of the story have been told, mainly within the field of economic history. ${ }^{3}$ Pam Oliver's research guide to the National Archives of Australia's records on Japan and Australia, identifies significant relevant records and states that "Early trade between Australia and Japan developed because of the Japanese army's need for woollen clothing and other supplies for its soldiers during the Sino-Japanese War of 1893-94."4 Certainly the difference in dress between the Japanese and Chinese armies and diplomats in prints depicting episodes of that war highlights Japan's 'modernization 'and 'westernization' of both services relative to China.

By the early 20th century, Japan was developing its own woolen textile industry to cut down on imports of finished cloth from the US and Europe. Indeed, a 1924 US business assessment of the Japanese woolen industry also attributed its origins to mills established in 1877 to weave woolen cloth to outfit the Japanese army in western style uniforms, although by the date of the article the industry had expanded to produce a variety of civilian and military goods. ${ }^{5}$ The fact that nearly all the raw wool to support this industry was imported placed Japan among the have-not nations competing for access to this strategic resource - with Australia at the center of this trade. Oliver's NAA records' guide states that Japan's first order of Australian wool in 1890 was 187 bales; that after 1900, Japan removed its import tax on wool; and that the trade grew until by 1939 more than 50 Japanese wool-trading houses operated in Australia. ${ }^{6}$ On the world stage, however, Japan's wool industry was overshadowed by its burgeoning cotton textile export industry, which expanded during World War I into markets in Asia and Africa that were difficult under wartime restrictions for the US and UK textile industries to continue serving. The US, UK, and Japan did

\footnotetext{
${ }^{2}$ Fabric of War : A Hidden History of the Global Wool Trade is a creative research project exploring the linked histories of wool and war, through print, digital media, and film.

${ }^{3}$ See for example: Kosmas Tsokhas, "British Economic Warfare in the Far East and the Australian Wool Industry," The Agricultural History Review, 41, no. 1 (1993).

${ }^{4}$ Pam Oliver. Allies, Enemies, and Trading Partners: Records on Australia and the Japanese, Research Guide \# 20. National Archives of Australia (2004), 15. Oliver's guide is extremely valuable, particularly in regard to Japanese wool buyers' business records.

5 "Growth of the Japanese Wool Manufacture." Bulletin of the National Association of Wool Manufacturers LIV (April 1924 ), 306.

${ }^{6}$ Oliver, 2004, 15-16.
} 
quite the diplomatic dance around the cotton trade: Japan purchased most of its raw cotton from the British Empire and the United States, contributing to the success of their agricultural interests, while simultaneously competing with those nations' manufacturing interests. ${ }^{7}$ In the 1930s, however, a need for foreign currency to support purchases of the materials necessary for the war with China led Japan to begin exporting woolen textiles, as well as cotton.

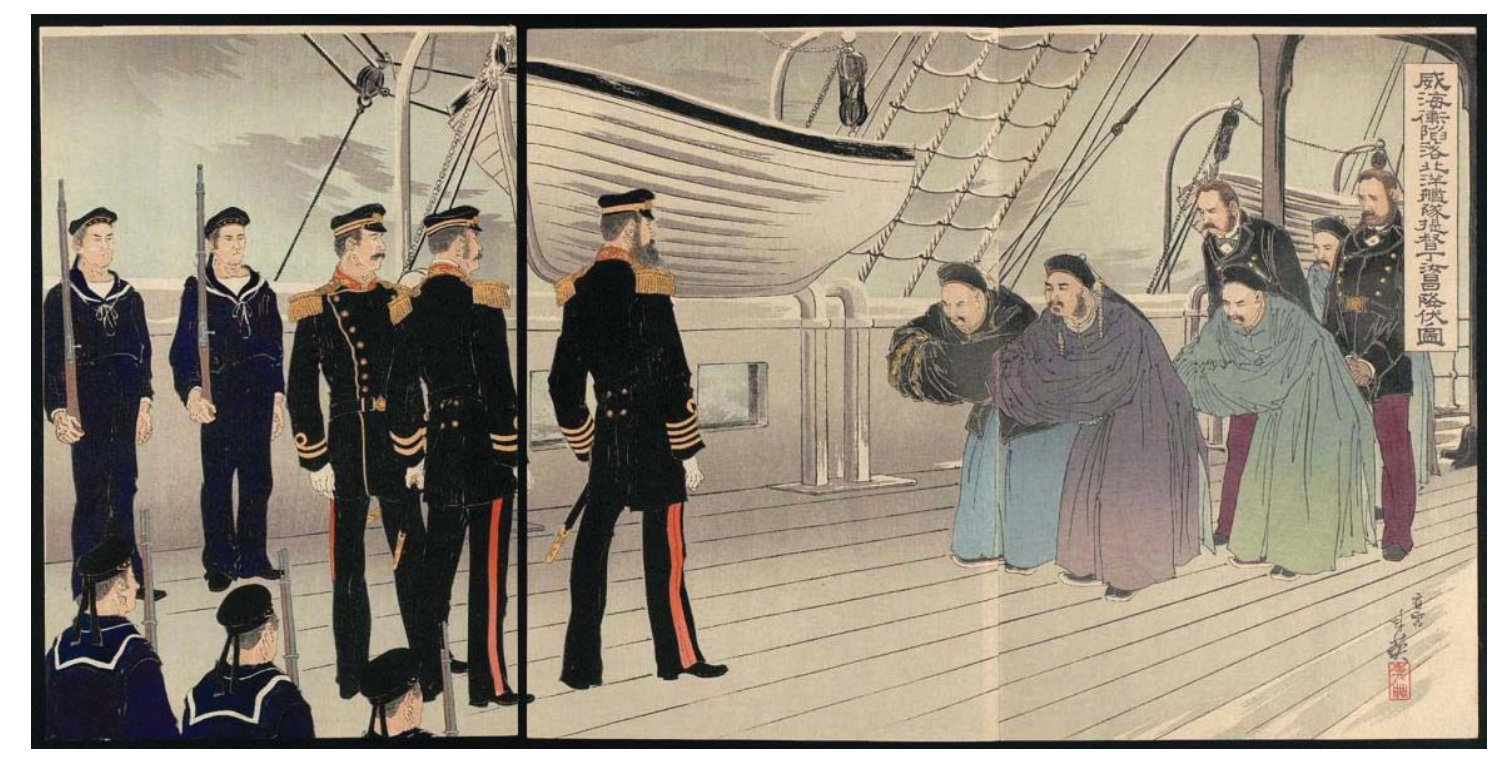

Figure 3. Migita Toshihide. Admiral Ding Ruchange Surrenders. 1895. Museum of Fine Arts-Boston. Note the wholly westernized clothing of the Japanese military and diplomatic representatives.

The other fiber that we presumed to be used in the suit, rayon, was, we knew, in fairly common use in a range of World War II-era military textiles by the US, UK, and Germany. Although rayon had been developed from cellulose fiber (initially from wood pulp) in the late 19th century, and became commercially available after 1911, not until it was successfully de-lustered (1927) and from 1928, was able to be processed into staple fiber (short, and spinnable into a cotton- or wool-like yarn), did it find broad usage. ${ }^{8}$ Even as a staple fiber however, rayon lost strength, did not retain warmth when wet, and was more flammable than cotton, silk, or wool.

\footnotetext{
7 See: Frank L. Walton, The Thread of Victory (New York, NY: Fairchild Publishing Co., 1945), 231-232; Kerry A. Chase, Trading Blocs: States, Firms and Regions in the World Economy. Chapter 3 - "Interwar Trading Blocs: Japan, Britain, and Germany, 1919-39.” Accessible at: https://www.press.umich.edu/pdf/047209906X-ch3.pdf; For more on Japan's cotton trade see Peter Duus, “Zaikabo: Japanese Cotton Mills in China, 1895-1937”, The Japanese Informal Empire in China, 1895-1937, P. Duus, R.H. Myers, and M.R. Peattie, eds., (Princeton University Press, 2014); The US Department of Commerce published several comprehensive reports written by Ralph M. Odell on the markets and opportunities for cotton goods in various parts of the world, including Asia, in the 1910s. ${ }^{8}$ For simplicity's sake we use rayon, chosen by the industry in 1924 as a generic name for regenerated cellulose fiber, throughout. Alternate names such as viscose and acetate denote different production processes, while the early term artificial silk denotes the fiber's original use. The history of regenerated cellulose fibers is well-documented. See, for example: Zelma Bendure and Gladys Pfeiffer, America's Fabrics: Origin and History, Manufacture, Characteristics and Uses. (New York: Macmillan, 1946), 163-220.
} 
These characteristics limited its military uses during World War II, in the Allied nations which had access to wool and cotton, to linings and light use apparel fabrics. ${ }^{9}$

In Germany, on the other hand, which had suffered serious fiber shortages in 1914-1918, and had invested heavily in rayon production during the interwar period, rayon had a larger part in both military and civilian textiles during the 1939-45 war. We were familiar with the efforts of Germany and Italy during the interwar period to develop new substitutes for natural textile fibers, and we knew that German uniform textiles incorporated significant percentages of rayon. ${ }^{10}$ But the Japanese dimensions of wool and rayon usage during the war, and how much fifty years of warfare in the Far East had influenced Japan's woolen industry, were new to both of us - and spurred further research.

By 1935 Japan was one of the big four rayon-producing nations, exporting about half its rayon fabric production - to Asia, Africa, Australia and even to the US, although tariff changes reduced the US market share some after 1929. At the same time, Japan became an even more important wool consumer, as it went to war in China, invading Manchuria in $1931 .{ }^{11}$ One of several research avenues we have yet to pursue is whether Japan and Germany exchanged information before and during the war on using rayon fibers in military products. Exploration of the fibers in the suit, and the context in which they had likely been produced, was one crucial step in realizing the possibilities for knowledge and engagement inherent in this object.

To really see how far this object could take us however, we needed to know more about the stories behind the suit, not only its country and context of manufacture, but also in how it had come to be hanging in a dusty cabinet, far from those places and those for whom it had been designed as a functional uniform in an extreme circumstance. To answer those questions, we

\footnotetext{
9 The Smithsonian Institution's National Museum of American History holds swatches of every fabric used to outfit the US military during the war, donated by the Army and Navy, including rayon linings, tropical weight shirtings, dress fabrics for the women's services, and mixed fabrics of cotton and rayon or rayon and wool. An important US textile firm, the Skinner Silk Company donated its trademarked double-sided rayon and wool 'Sunbak' fabric, which contrasted a smooth, tightly-woven, wind-resistant rayon face with a brushed wool pile. This was used as an insulating jacket lining. NMAH/SI: US Army Textile Samples, Accession \# 172295; US Navy Textile Samples, Accession \# 172665; William Skinner \& Sons Sunbak fabric lengths, T.09677.000 (khaki) and T.09678.000 (olive drab). For rayon in US civilian blended fabrics see John W. Klein, "Wool During World War II", War Records Project Monographs, No. 7. (USDA, Bureau of Agricultural Economics, May 1948), 49.

10 See Stephen J. Kennedy, "Fiber Blends in Military Textiles," Journal of the Textile Institute Proceedings, 43:8, (1952), 681-698, DOI: 10.1080/19447015208664085; Leroy H. Smith, et. al. (Technical Industrial Intelligence Committee), "New Fibers and Their Applications in Germany During the War Period," (Field Information Agency, Technical, Final Report No. 44, 14 Sept 1945); P. Alexander and C.S. Whewell. (British Intelligence Objectives Sub-Committee), Some Aspects of Textile Research in Germany. B.I.O.S. Final Report No. 1472. Item No. 22. (London: HMSO. 1946); “War Stimulates Nazi Research for Substitutes," Boston Globe, 26 Dec 1939, 16. ProQuest Historical Newspapers. Recently, Kassia St Clair discussed forced labor in German rayon plants, The Golden Thread: How Fabric Changed History, (London: John Murray publishers, 2018), 208-211.

${ }^{11}$ Manpower, Food, and Civilian Supplies Division, The United States Strategic Bombing Survey, The Japanese Wartime Standard of Living and Utilization of Manpower. (Washington, DC: January 1947), 37-38. This is a concise but astute look at Japanese textile production before and during World War II, containing important statistics re production, imports, and exports for both civilian and military textiles. See also: Kyoko Sheridan, The Structure of the Japanese Wool Textile Industry. Wool Economic Research Report No. 16. (Canberra: Bureau of Agricultural Economics, 1969).
} 
needed to find out why the suit had been donated to an Australian outback local history museum and what the suit meant to the family that had been its carers for several decades before donating it to the Pioneer Park. In our own experience of studying and exhibiting textiles related to the American Civil War, we knew that objects such as this can:

give insight into the experience of war and how those experiences were processed, remembered, and transformed into public history. As such, they give voice to the voiceless and presence to the anonymous. Allowed to relate their own intimate stories, they illuminate issues of national significance. ${ }^{12}$

In this way material culture can itself be a powerful primary source for history, indeed, inspiring and supporting new research rather than simply illustrating existing histories. ${ }^{13}$

Lauren Reid, a Berlin-based curator in the field of anthropology, has written recently of the way that she was "struck" by the way objects in museums often live a "seeming double life": one before and one after the moment when they are collected by an institution and "born again as ethnographic objects". ${ }^{14}$ In this instance, this object could be seen to have had at least three lives already: one as a presumably very ordinary piece of military equipment; a second after having been purloined for a private family collection; and a third and possibly final life as an item in the Pioneer Park collection. Our next move then was to explore the flying suit's second life.

Elaine Fox, at the Pioneer Park Museum, put us in touch with the lender of the suit, Wally Lanagan. Several subsequent telephone and email exchanges, followed by a filmed interview, as discussed further below, slowly uncovered the intriguing story of the suit's place in a complex family history. It begins with Wally's father's cousin, Corporal Alfred Henry Lanagan, who was a flight engineer in the Royal Australian Air Force on a Catalina flying boat during the Battle of the Coral Sea in May 1942. ${ }^{15}$ His aircraft was shot down during the battle and the crew listed as missing, presumed dead. Later it would be learned that Alfred was captured alive and taken to a prisoner of war camp near Rabaul on New Britain. Sometime after November 1942 he was executed by the Japanese - having first been listed by them as a POW. Not until 1950 was his body recovered and more detail about the timing and manner of his death come to light. He was then reburied in the Bita Paka War Cemetery near Rabaul. ${ }^{16}$

\footnotetext{
${ }^{12}$ Madelyn Shaw and Lynne. Z. Bassett, Homefront \& Battlefield: Quilts \& Context in the Civil War. (Lowell, MA: American Textile History Museum, 2012.), 3.

${ }^{13}$ For an example of this, see Madelyn Shaw and Amy J Anderson, "Ivory for Cotton - Textile Trade Documents at the National Museum of American History," Curator 61, 1, (January 2018).

${ }^{14}$ Lauren Reid, "The Secret Life of Objects: Strategies for telling new stories in exhibitions \#LivesofObjects", Allegra lab:Anthropology for Radical Optimism, September 18,2018, https://allegralaboratory.net/the-secret-life-ofobjects-strategies-for-telling-new-stories-in-exhibitions-lifeofobjects/, accessed January 10 ${ }^{\text {th }}, 2021$.

${ }^{15}$ Whilst the label on the suit in the Pioneer Park said he was a 'Naval Aviator', all available sources, including his war record from the Australian War Memorial, confirm him as a member of the Australian Air Force.

${ }^{16}$ Hunter Valley Military History, Facebook post 7 May 2016

https:/www.facebook.com/HunterValleyMilitaryHistory/posts/990444687714923:0 tells the story of this battle and therein quotes a Department of Air, Australia document, 11 December 1946 saying that Alfred Lanagan and others "officially presumed to have lost their lives with effect 4th May, 1942". This same document goes on to detail the current understanding of what happened, which is still in several regards contested. This event is also discussed in an interview, undertaken for the Fabric of War project with Wally Lanagan, May 27 2019.
} 
Meanwhile, this airman's suit had been brought home by two of Wally's Uncles - Norm and Les McKenzie - infantrymen in the Australian army in New Guinea - as a war souvenir for their sister, Wally's mother. ${ }^{17}$ Souvenir - from a root that means literally an object that will bring something previously seen to mind - is the word that Wally used to describe how this object came to his family. But the word 'trophy' is also appropriate if the wider meanings of the airman's flying suit are to be uncovered. One definition of 'trophy' is "a spoil or prize of war", a symbol of success. ${ }^{18}$ Jennifer Wellington has recently undertaken extensive analysis of the $20^{\text {th }}$ century history of gathering war trophies. While rooted in ancient history, she analyses the way that the practice came in the First World War to be extensively organized by governments, and how the national war memorials in the United Kingdom, Canada, and Australia were set up during that war to display these objects, thereby mobilizing popular support for the prosecution of that war and the preparation for future military conflicts. ${ }^{19}$ Most of these war trophies were armaments and vehicles, including airplanes and tanks, but helmets, paintings and photographs, and personal accoutrements were also gathered. ${ }^{20}$

Textiles other than flags do not figure highly in Wellington's account, but many examples survive. The Australian War Memorial collection contains display boards mounted with the identifying shoulder straps from uniforms of German units captured in August and September 1918, under the direction of Lt. Gen. John Monash, to be exhibited in Australia as a charity fundraiser. ${ }^{21}$ These served two purposes: symbolic, as a trophy of success in war; and practical, documenting the identities of the enemy units faced. Textiles were also collected as a source of information about the strategic technologies they represented. At the end of the First World War, a large collection of salvaged German war material was brought to the United States and sent on a 'trophy' tour of the nation. But when the tour came to an end in 1923, Frederick Lewton, the US National Museum's curator of textiles, selected various pieces of military equipment - shovel covers, wagon tarps, ammunition bags, feed buckets, and the like - for permanent custodianship. These objects were made of twisted paper yarns, a technology adopted by the Germans in response to dire shortages of textile fibers during the war. Having faced similar, albeit less dire, shortages, the US wanted to explore all relevant technologies that might help the nation survive future wars. ${ }^{22}$ The collection of enemy possessions has a long history, for both symbolic and practical ends.

As we became familiar with Wally's story, it was apparent that the meanings of this particular souvenir had additional nuances to those discussed above. There were twelve siblings in Wally's mother's generation of the Mackenzie family: in addition to the two brothers that brought back the suit (and also a Japanese sword and a silk parachute that got turned into dolls' clothes), a

\footnotetext{
${ }^{17}$ Interview with Wally Lanagan, 2019.

18 https://www.etymonline.com/word/trophy

${ }^{19}$ Jennifer Wellington, "War Trophies, War Memorabilia, and the Iconography of Victory in the British Empire." Journal of Contemporary History 54 (2019), 758.

${ }^{20}$ Wellington, 2019, 744.

21 See www.awm.gov.au/collection Accession number RELAWM15049.004.

22 These objects and their historical context are discussed in Madelyn Shaw and Amy Anderson, 'The Consular Collections at the National Museum of American History', Crosscurrents: the Transnational Flow of Textiles, Symposium of The Textile Society of America, 2016. https://digitalcommons.unl.edu/tsaconf/1000
} 
third brother in the infantry in New Guinea died fighting the Japanese; and a fourth, serving in Europe, spent several years as a prisoner of war on Crete. This was a family that suffered disproportionate losses from their 1940s military service. Wally grew up with a grim awareness of Japanese military might and its impact on his country and family. We can only speculate what part the retrieval of this suit and its passage through the hands of several family members as curators may have played in their individual and collective psychology after the war. We asked Wally if taking the suit might have been an attempt by his uncles to 'even the score' - i.e. to take from Japan something equivalent to what had been lost to that nation in war - but he denied this motivation. He did say however that his Uncle Les was one to "put up a fight and I suppose it was something he was going to hang onto'. ${ }^{23}$ Perhaps the suit was as much a relic - a memorial of loss - as a trophy. The individual will to acquire enemy possessions, to take home souvenirs or remembrances of one's part in a large, shared undertaking, can be as much about the psychology of loss as of victory in war, and this is part of our reading of the flying suit.

While researching the Lanagan and Mackenzie family histories to understand the suit's 'second life', we had asked a colleague, Koichi Okamoto, a professor of history at Tokyo's Waseda University, to translate the label. His reading gave us the name of the factory that made it: The Yokosuka Military Department, and the year and month it was made, December 1942. Originally known as the Yokosuka Munitions Factory, the Department had been expanded and renamed in 1923. The label also has three empty columns, theoretically for more than one aviator's name, yet there is no trace of ink - and no suggestion that there ever were names on the label. There is also the tantalizing term, "Rental Supply", before the Yokusuka name. ${ }^{24}$

This information, part of the suit's original life, is also relevant to understanding the stories that Wally's family wove around it whilst they were its custodians. When we first saw the suit, we had been surprised at its cleanliness and general good condition - except for one hole on the left thigh. Wally said that in his family folklore, this was a bullet hole, with the implication that the suit was recovered from a dead or wounded Japanese soldier. But the circumstances of its acquisition and pathways from its original owner to Australian infantrymen are unclear. To the naked eye the hole seemed neither large nor elaborate enough to have been made by a bullet. It may have been 'liberated' by Wally's uncles from a storehouse, and not ever been used, or the term on the label, "Rental Supply" may mean that such garments were part of a central depot: given out as needed, used, and returned. Or perhaps, as with recycling of military uniforms in other wars, by other nations, it was easier to re-issue a uniform that did not bear the name of a dead or wounded comrade. ${ }^{25}$ It is another mystery that only additional research and advice from historians of Japanese military supply chains can help us solve.

Talking to Wally pushed us to understand more broadly the context of the Japanese wool trade and the part Australia played in it. Between our two trips to Dalby, we visited the Canberra

23 Lanagan, 2019. Mackenzie was Wally Lanagan's mother's family name prior to her marriage

24 Email Correspondence, Koichi Okamaoto. May 16, 2019. Translation of the Airman's suit label: "Rental supply The Yokosuka Military Department / The Year and Month of the production - 1942 December (The year of 17 [Japanese imperial calendar, Showa], the month of 12)/ Size 4 / Name"

${ }^{25}$ For a discussion of recycling uniforms in World War I, see Madelyn Shaw and Trish FitzSimons, "Wool, Paper, Dye: 1917 and the Roots of the Synthetic Fibre Revolution" in The Enduring Impact of the First World War: A Collection of Perspectives, Gail Romano and Kingsley Baird, eds. Bulletin of the Auckland Museum, 21 (2020), 02. 
Repository of the National Archives of Australia, to search through records on the textile trade between Australia and Japan in the years between the two world wars. The documents are scattered among many record groups and across repositories in several Australian cities. We examined enough of the records held in Canberra to know that a thorough investigation into this trade could shine a hard light on the metaphoric diplomatic tightrope-walking during that period of global economic woes. The documents reveal Australia's anxieties about its need to prop up its domestic economy by cultivating new or expanding markets for its raw wool, while maintaining its preferential trade relationships within the British Empire. A further complication was the real possibility that by selling wool to Japan, then expanding its power in Asia, Australia was aiding a future enemy to prepare for a shooting war that would be fought - at least partly - by military personnel exposed to conditions in which wool would be a vital resource for both safety and comfort. ${ }^{26}$ Interviewing Wally on our second visit to Dalby led to another exciting moment, when Wally recounted his father's ironic comment that the suit was made of Australian wool. We scoured and analyzed archival documents with this statement in mind.

The National Archives' holdings, of correspondence, memoranda, policy drafts, clippings from newspapers, trade agreements, and a variety of political, economic, and intelligence reports, detail the vicissitudes of the Japan-Australia wool trade. They show that as early as World War I, Australia took Japan's position as a consumer of its wool very seriously. In response to British control of the best wools during that conflict, for example, woolen manufacturers in both Japan and the US increased their capacity for carbonising (treating raw wool to remove vegetable matter) lower quality wools. Several requests for permission to export such wools to Japan from Australia were filed. ${ }^{27}$ Japan's efforts to establish its own sheep pastoralism had been unsuccessful - due largely to a dearth of suitable fodder grasses according to one observer, and Australian wool-brokers were happy to serve this up and coming market. ${ }^{28}$ Perhaps of note, given Japan's later success in manufacturing wool-rayon blended and mixed fabrics, was an Australian diplomat's description of Japan's fulfillment of contracts to supply Russia with woolen textiles in early 1916, as incorporating "only 20 per cent of Australian wool [with] the balance consisting of 15 percent New Zealand crutchings, 20 per cent China wool, and the rest Japanese wool waste." 29 This suggests that by World War II the Japanese had long experience of blending fibers into textiles that balanced cost and availability against quality.

\footnotetext{
26 A summary of Australia-Japan trade relations can be found in "Australia and Japan - A Trading Tradition", Chapter 5 of Japan's Economy Implications for Australia. (17 August 2000) at https://www.aph.gov.au/Parliamentary_Business/Committees/Senate/Foreign_Affairs Defence and Trade/Complet ed inquiries/1999-02/japan/report/c05. Tsokhas, 1993, 44-59, describes the Japan-Australia trade, but primarily in terms of the UK's influence over and stake in that trade.

${ }^{27}$ See, for example (all National Archives of Australia, henceforth NAA): A456; W/29/4/2 Export Wool to Japan 1915-19; A2 1917/3510 part 5 Wool Clip 1916-17, Shipments to Japan; W/156/16/72 Minute Paper, Department of Defense. Request from John Bridge \& Co., Ltd., Woolbrokers; A3932, SC52 - 89/253/1 - Wool Situation in Japan - Ref Memo of 6th Sept. 1917.

${ }^{28}$ NAA: A2 1917/3510/part 5. Wool Clip 1916-17. Letter Re Wool Growing in Japan.

${ }^{29}$ NAA: A3932, SC52 - 89/253/1 - Wool Situation in Japan - Ref Memo of 6th Sept. 1917. E.F. Crowe. Enclosure 4 in No 1 Memorandum (B); Notes on the Japanese Woollen and Worsted Industries, follow-up to report of 1 Feb 1916,64 .
} 
The archives also displayed the intelligence-gathering on the wool trade resulting from Australia's national interest in wool. Australian diplomat J.G. Latham's 1934 report, for example, discussed Japanese efforts to increase their local wool supplies by encouraging sheepraising in Japanese-occupied Manchukuo (known before and after the occupation as Manchuria). Latham concluded then that Australia need not worry unduly about this adversely affecting Japan's appetite for Australian merino wools. ${ }^{30}$ In 1936 and 1938, the Australian government negotiated trade agreements which in part balanced the quantity of wool exported to Japan against the quantity of Japanese-made rayon fabrics designed to imitate wool that Australia was prepared to import in return. ${ }^{31}$ In the later 1930s and well into 1941 the government granted permits for the export of wools to textile factories in Manchukuo and in Shanghai, but the memos and meeting minutes that document the rationale for the approvals have not (as of this writing) been uncovered. ${ }^{32}$ Records of a Japanese wool buying firm based in Melbourne exist in the NAA repository there but have not been reviewed. We hope in a planned grant application to fund a PhD student to work on the Japan-Australia wool trade, not only in the Archives in Australia and Japan, but in records from other countries that would help to flesh out this story one of international scope with Australia's political economy at its heart. ${ }^{33}$

But in the meantime, the documents we have read in the NAA certainly support the statement that Wally's father made about the suit: it is very likely that, as the war in the Pacific began Australian wool, from pre-War Japanese stockpiling of this vital military commodity, was indeed at least half the fiber in this garment. It is also likely that the fabric conserved wool by combining it with Japanese rayon. Wool, a vital resource for war-making, had continued to be exported by Australia to Japan, several years after a furor in Australia over exporting "scrap metal" to Japan that could be turned into munitions. This had earned then Australian Attorney General, Bob Menzies, the moniker 'Pig Iron Bob'. Although from 1939 the British worked to limit the amount of Australian wool that Japan could import, partly by way of reducing the chances that Japan would purchase Australian wool on Germany's behalf, no concomitant 'woolly' nickname for the Australian Prime Minister arose. ${ }^{34}$ We see this as evidence of how wool as a strategic military commodity has tended to 'slip under the radar' of both the public imagination and military historians.

In addition to our academic interest in the 'What' of the Japanese airman's suit and the 'Why' of how it ended up in a rural and local Australian museum, we also felt that, given the uncertain conditions at the Pioneer Park Museum, we needed to consider 'How' best to preserve the suit

\footnotetext{
${ }^{30}$ NAA: A981 - Far 5 Part 16 Far East. Australian Eastern Mission 1934, Report of the Right Honorable J. G. Latham, Leader of the Mission, 20. [The Mission travelled in China and Japan in 1932-33.]

${ }^{31}$ See: NAA: A1667. 194/B/5 Part 1. Reciprocity - Manchukuo Trade - 1936; 194/B/3/A7-01 Trade \& Customs Dept. Japan Treaty negotiations. Textile Wool Arrangement. Trade Agreement, Treaty Series No. 66 (1938), 3.

${ }^{32}$ See, for example: NAA: A1539 1939/W/133. Export of Wool. F. Kanematsu Pty. Ltd.: A1539/W/140 Export of Wool - Japan Cotton Trading Co., Permit Application for the Canberra Maru, dated Sept 13, 1939; A1539/1 1940/W/13672 26 Aug 1940 - Wool tops to Shanghai Worsted Mill; 1941/W/2567 11th Release of 25,000 bales of wool to Japan, March 1941; A1539/1 1941/W/1333b Wool to Shanghai 20 Nov 1941.

${ }^{33}$ The US National Archives and Records Administration holds a Japanese propaganda film tentatively dated to 1939 which includes Manchurian sheep among the resources considered essential to Japan. (NARA ID\# 44302. Series: Motion Picture Films From G-2 Army Military Intelligence Division, 1918 - ca. 1947. Record Group 242: National Archives Collection of Foreign Records Seized, 1675 - 1958).

${ }^{34}$ Tsokhas, 1993, 45-49.
} 
and ensure it was accessible to other researchers. We decided to document it on video and through a three-dimensional scan and at the same time to film an interview with Wally Lanagan about the suit and his family's links to both Japan and to the wool trade. Trish hired a film crew and negotiated with her University for the loan of a colleague and his high end, handheld 3D Scanner to capture the garment in its entirety. We borrowed a male mannequin from the Queensland Museum, whose staff could not have been more helpful, and off we went back to Dalby, a few weeks after our first visit and just before Madelyn's grant - and visa - expired. Fortunately, the mannequin was not too big around, although it was a few inches too tall - but with great care we got the suit onto the mannequin.

And while conditions for scanning were not ideal in a shed at the Pioneer Park, the process was fascinating, and a new one for all of us. For Trish - a filmmaker - this was an utterly different approach to image-making. For Chris Little - Griffith University's expert on 3D scanning - this represented an interesting transition from scanning the Sydney Opera House and a WWI tank to scanning a garment for the first time. For Madelyn - a curator - it opened new windows into object preservation, and to new means of public access and engagement. The resultant high resolution image preserves (for the life of the scan at least) details of the garment's construction and history. These have the potential to answer questions like 'Is that really a bullet hole in the thigh?' which has exercised Wally's family for decades. The scan could, of course, also be useful to costume historians or film production designers anywhere in the world wanting details of the uniform's form and construction, without actually needing to access the object.

\section{https://sketchfab.com/3d-models/wwii-airmans-suit-a3aceab5d8314bd28a0e864d2cc24606}

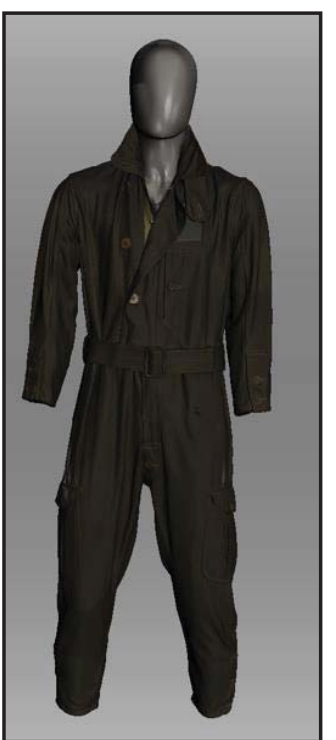

Figure 4. Still composite of the scan of the Japanese Airman's suit. To see in 3D, click on URL. Password: Suit. Click on hotspot 1 to see close up of hole. Click on Hotspot 2 to see the internal label

Covid-19 and a grant application rejection have delayed the production of the textile history interactive we have planned around the Japanese Airman's flight suit, using the 3D scan. Eventually the scan (see link to Figure 4, above) will be the centerpiece of a module that incorporates scans of archival documents, historical images and graphics, interview clips, and 
interpretive text. It may also be possible to include some forensic examination of the hole in the suit, which might clear up for us how it was made. Looking at the scan through a virtual reality headset and even in this lower resolution version it appears much more likely that Wally's family folklore of the bullet hole could be true, than it does to the naked eye.

We are both proud of this scan and frustrated by the means that we currently have to share it. For an earlier element of our Fabric of War project, we developed a 2D interactive of an American Civil War greatcoat based on RAW ultra-high-resolution photographic files that allow a user to get right into the fine detail of fabric. This high-resolution detail exists in the 3D scan, in a form that could eventually also be used in holograms and virtual reality. But that detail is not yet available through our current viewing software. Institutions and scholars are still working out how best to use this powerful technology: in the Australian War Memorial, for instance, one can access similarly tiny $3 \mathrm{D}$ models that lack the visual power of a quality photograph.

As mentioned earlier, the airman's suit and its story are deeply entwined with the Lanagan family's experience of war, and its long-term emotional effects. The filmed interview with Wally Lanagan has wonderful further context that attests to the power of this object: His wartime memories include being grabbed tightly by his mother as a small child when a plane that she thought was a Japanese war plane flew over their sheep station in outback Queensland. He remembers too at the end of the war his father constructing an effigy of Japanese General Tojo. This was dragged by a rope around its neck behind their car into town and burned in front of the whole community. The front of the family car meanwhile had a stuffed kangaroo attached, as a symbol of national and local pride in victory. But Wally also recounts how the family slowly came to terms with Japan's transition from hated enemy to friendly neighboring nation and important trading partner, just as of course it had been before the war. Having grown up around the suit as a family treasure/curiosity and talking point since he was a child, Wally on Mother's Day in 2005 for the first time donned the suit. He says that he considered wearing it when undertaking mechanical repairs on his car, but instead decided to donate it to the Pioneer Park, where he and his wife Bev are keen volunteers. Thus did we find it hanging in a case of many disparate uniforms in 2019. Bringing together the rich potential of the technology and the 
breadth and depth of the contextual resources that we have uncovered is a challenge that awaits us.

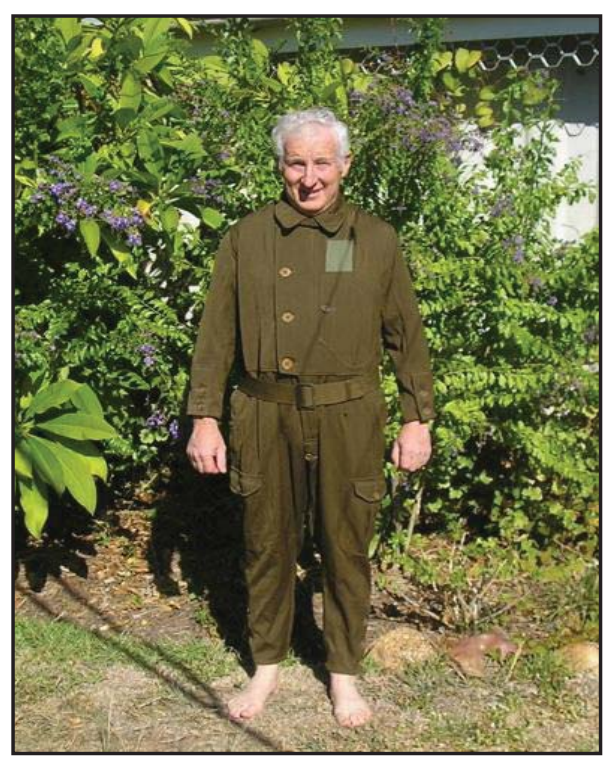

Figure 5. Wally Lanagan in the 'souvenir' Japanese Airman's suit. 2005

What then is our answer to the question of "How Far Can (this) Object take Us"? Clearly any answer in this paper is going to be provisional, given that our work with the airman's suit is still a work in progress. Samuel Alberti argues that 'objects gather meanings through associations with people they encountered on the way to the collection'. ${ }^{35}$ And following from Reid and Wellington there is no reason to imagine that this process of accreting meaning will end once an object becomes part of a personal or an institutional collection. Ever and always, it depends what set of questions is brought to the object. In our case, finding this object as part of our research of a transnational commodity history of the intersection of wool and war formed and framed the contextual research that we undertook.

To summarize then some of the object lessons from the suit as we currently understand it. First, as mentioned earlier, it reminds us to recognize the valuable role that small museums and historical societies and their collections play in preserving our history. Second, how closelooking and questioning of what appeared to be a pretty straightforward military garment transformed it into a testament to the complexity of the global wool trade. Broader histories of several different kinds are encapsulated in this one object. These include but are surely not limited to the very specific meanings that the Lanagan/Mackenzie families give to the suit. For some 150 years wool was Australia's major export commodity, and the strategic and economic dimensions of this trade needed to be balanced. ${ }^{36}$ This suit likely represents the Japanese experience of that balance: shortages of wool forced nations on the short end of the UKdominated supply chain to seek out new ways to meet their needs, with long term effects on the world's textiles. And finally, for us as interpreters of this object, our research into and treatment of this suit demonstrates the potential for audio visual and digital technologies to enhance the

\footnotetext{
${ }^{35}$ Samuel Alberti, “Objects and the Museum”, Isis, 96, No. 4 (December 2005), 559.

36 Trish FitzSimons and Madelyn Shaw, Fabric of War: Why Wool, Video, 13 minutes, 2018.
} 
curatorial process, bringing out the meanings and context of material culture objects. Our chance encounter with this particular suit predicated a deeper dive into the role of textiles as war trophies, the role of war in facilitating the creation and adoption of factory produced fibers and the way that the war impacted families on the home front. We hope to share the outcome of all of the above with you in the near future. 


\section{BIBLIOGRAPHY}

Alberti, Samuel. "Objects and the Museum”, Isis. Vol. 96, No. 4 (December 2005).

Alexander, P. and C.S. Whewell. British Intelligence Objectives Sub-Committee. Some Aspects of Textile Research in Germany. B.I.O.S. Final Report No. 1472. Item No. 22. London, HMSO. 1946.

Bulletin of the National Association of Wool Manufacturers. Vol. LIV, April 1924.

Duus, Peter. "Zaikabo: Japanese Cotton Mills in China, 1895-1937", in The Japanese Informal Empire in China, 1895-1937, P. Duus, R.H. Myers, and M.R. Peattie, eds., Princeton University Press, 2014.

FitzSimons, Trish and Madelyn Shaw. Fabric of War: Why Wool, Video, 13 minutes, 2018

Hatase, Mariko. "The Effects of Sharp Depreciation of the Yen in the Early 1930s." Monetary and Economic Studies (October 2002) pp.143-180.

Kennedy, Stephen J. "Fiber Blends in Military Textiles”, Journal of the Textile Institute Proceedings, 43:8, (1952) P681-P698, DOI: 10.1080/19447015208664085

Klein, John W. Wool During World War II. War Records Project Monographs, No. 7. May 1948. United States Department of Agriculture, Bureau of Agricultural Economics.

Manpower, Food, and Civilian Supplies Division, The United States Strategic Bombing Survey. The Japanese Wartime Standard of Living and Utilization of Manpower. January 1947.

Oliver, Pam. Allies, Enemies, and Trading Partners: Records on Australia and the Japanese. Research Guide \# 20. National Archives of Australia (2004).

Parliament of Australia. “Australia and Japan - A Trading Tradition”, Chapter 5 of Japan's Economy Implications for Australia. (17 August

2000) at https://www.aph.gov.au/Parliamentary_Business/Committees/Senate/Foreign_Affairs_Defence_and Trade/Completed inquiries/1999-02/japan/report/c05

Reid, Lauren. "The Secret Life of Objects: Strategies for telling new stories in exhibitions \#LivesofObjects", Allegra lab:Anthropology for Radical Optimism, September 18, 2018, https://allegralaboratory.net/the-secret-life-ofobjects-strategies-for-telling-new-stories-in-exhibitions-lifeofobjects/

Shaw, Madelyn with Amy J. Anderson. " Ivory for Cotton - Textile Trade Documents at the National Museum of American History." CURATOR: The Museum Journal. Volume 61, Issue 1. January 2018. https://doi.org/10.1111/cura.12217

Shaw, Madelyn and Anderson, Amy J.. "The Consular Collections at the National Museum of American History" Opening Plenary Session: Crosscurrents: the Transnational Flows of Textiles" (2016). Textile Society of America Symposium Proceedings. 1000. https://digitalcommons.unl.edu/tsaconf/1000

Shaw, Madelyn and Lynne. Z. Bassett. Homefront \& Battlefield: Quilts \& Context in the Civil War. American Textile History Museum, 2012.

Shaw, Madelyn and Trish FitzSimons. "Wool, Paper, Dye: 1917 and the Roots of the Synthetic Fibre Revolution" in The Enduring Impact of the First World War: A Collection of Perspectives. Bulletin of the Auckland Museum, Volume 21 (2020). Edited by Gail Roman and Kingsley Baird.

Sheridan, Kyoko. The Structure of the Japanese Wool Textile Industry. Wool Economic Research Report No. 16. Bureau of Agricultural Economics, Canberra. 1969.

St Clair, Kassia. The Golden Thread: How Fabric Changed History, John Murray Publishers, London, 2018.

Textile World Journal. Feb 12, 1921.

Tsokhas, Kosmas. "British Economic Warfare in the Far East and the Australian Wool Industry. The Agricultural History Review, Vol 41, No. 1 (1993).

Walton, Frank L. The Thread of Victory. Fairchild Publishing Co., Ny, NY. 1945.

Wellington, Jennifer. Exhibiting War: The Great War, Museums and Memory in Britain, Canada and Australia, Cambridge University Press, 2017.

Wellington, Jennifer. "War Trophies, War Memorabilia and the Iconography of Victory in the British Empire", Journal of Contemporary History 2019, Vol. 54(4).

National Archives of Australia Record Groups

A2 1917/3510; A456; W/29/4/2; A981 - Part 16; A1539 1939/W/133; A1539/1 1940/W/13672;

A1539/1 1941/W/1333b; A1539/W/140; A1667. 194/B/5; A3932, SC52 - 89/253/1 - A3932; 194/B/3/A7-

01 Treaty Series No. 66 (1938). 